\title{
SYNTHESIS OF DNA COMPLEMENTARY TO I4S CALF LENS CRYSTALLIN MESSENGER RNA BY REVERSE TRANSCRIPTASE
}

\author{
Anton J.M. Berns and Hans Bloemenda $1^{*}$ \\ Laboratorium voor Biochemie, Universiteit van Nijmegen, Nijmegen, Nederland \\ Stephen J. Kaufman and Inder M. Verma \\ Department of Biology, Massachusetts Institute of Technology, Cambridge, \\ Massachusetts 02139 U.S.A.
}

Received April 13,1973

\section{SUMMARY}

The 145 messenger RNA (mRNA), coding for the $A_{2}$ chain of $\alpha$-crystallin was isolated from calf lens polyribosomes by zonal centrifugation and further purified by oligo(dT)-cellulose chromatography. The purified mRNA was used as a template to synthesize complementary DNA by reverse transcriptase. The DNA product appeared to be smaller in size than the RNA template but a faithful transcript of base sequences in the $14 S \alpha$-crystallin mRNA.

\section{INTRODUCTION}

In vitro synthes is of DNA complementary to several eukaryotic mRNAs by the avian myeloblastosis virus (AMV) DNA polymerase has been recently reported (1-6). Most eukaryotic mRNAs have been shown to contain regions rich in adenylic acid $($ poly $(A))(7)$ as an integral part of their structure. If these poly(A) regions are located at or near the $3^{\prime}$ end of the RNA, then an oligomer of (dT) can hydrogen bond to it and serve as primer to support the synthesis of complementary DNA by the reverse transcriptase. The 145 lens mRNA has been shown to contain poly(A) containing regions (8) and can thus serve as a template for the reverse transcriptase using oligomer of (dT) as primer.

In this communication we describe the synthes is of DNA complementary to the $14 \mathrm{~S}$ calf lens mRNA that codes for the $A_{2}$ chain of $\alpha$-crystallin $(9,10,11,12)$.

\section{MATERIALS AND METHODS}

Calf lens polyribosomes were isolated as described earlier (13). RNA was prepared by a chloroform-phenol extraction procedure described by Perry et al (14). The lens mRNA was purified by zonal centrifugation followed by oligo(dT)-cellulose chromatography (15) which resulted in a further 3 to 4 fold purification. The ability of the RNA to direct the synthes is of $\alpha$-crystallin polypeptides in vitro was tested as described elsewhere (12). The reverse transcriptase from avian myelo* to whom requests for reprints should be addressed 


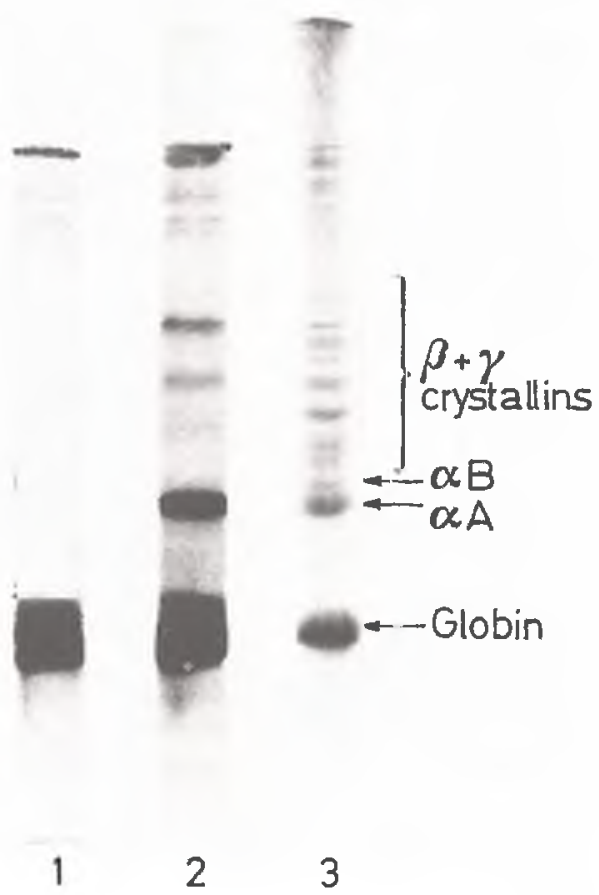

Figure 1. Identification of 145 lens mRNA directed translational products, 35 Calf lens mRNA was added to a reticulocyte lysate with highly labeled ${ }^{35} \mathrm{~S}$-methionine as described in ref. 12. After incubation an acidic acetone precipitation was carried out. The in vitro products were analyzed by SDS gel electrophoresis according to Laemmli (19). To each gel about $200 \mu \mathrm{g}$ of protein was applied. $20 \mu \mathrm{g}$ of crystallin polypeptides were added in order to compare the radioactive pattern with the stained bands. After staining and destaining longitudinal slices were dried down on filter paper under vacuo and autoradiographed for 3 weeks. The details of the procedure are described el sewhere (12).

1) without $14 S$ mRNA 2) with $14 S$ mRNA 3) stained ge1

blastosis virus was purified according to Verma and Baltimore (5). The single strand specific nuclease from Aspergillus oryzae was a generous gift of Drs.

D. Housman and A. Skoultchi.

The reaction mixture consisted of the following components: $50 \mathrm{mM}$ Tris- $\mathrm{HCl}$, $\mathrm{pH} 8.3,20 \mathrm{mM}$ dithiothreiotol, $6 \mathrm{mM}$ magnesium acetate, $60 \mathrm{mM} \mathrm{NaCl}, 600 \mu \mathrm{M}$ of the three unlabeled deoxyribonucleoside triphosphates, $80 \mu \mathrm{M}$ of the ${ }^{3} \mathrm{H}$-labeled deoxyribonucleoside triphosphate, $10 \mu \mathrm{g} / \mathrm{ml}$ oligo(dT) $12-18100 \mu \mathrm{g} / \mathrm{ml}$ Actinomycin $\mathrm{D}, 0.2$ to $0.5 \mu \mathrm{g}$ of reverse transcriptase and $6 \mu \mathrm{g} / \mathrm{ml}$ of $14 \mathrm{~S} \mathrm{mRNA}$. Incubations were carried out at $37^{\circ} \mathrm{C}$ for the specified times. The amount of incorporation was determined by measuring the acid-precipitable radioactivity as described previously (16). 


\section{TABLE 1}

\section{REQUIREMENTS FOR DNA SYNTHESIS USING 14S CALF LENS mRNA AS TEMPLATE}

$\begin{array}{lc}\text { Exp. I } & \text { pmoles dGMP incorporated } \\ \text { Complete } & 15 \\ \text {-Actinomycin } & 25 \\ \text {-dTTP } & 2.3 \\ \text {-dCTP } & 2.5 \\ \text {-dATP } & 2.5 \\ \text { +RNAase } & 1.7\end{array}$

Exp. II

Complete

43

$-0 l i g o(d T)+o l i g o(d G)$

29

-oligo(dT)+oligo(dA)

-oligo(dT)-oligo(dC)

4.5

-primer

4.1

Except where indicated, the complete reaction mixture described in the experimental section was used. The amount of RNA in exp. I and exp. II was 850 pmoles nucleotides of RNA. 01 igomers of dT, dG, dA and dC have chain length of approximately 12-18 nucleotides long and were obtained from Collaborative Res. Waltham, Mass. The ribonuclease reagent contained $400 \mu \mathrm{g}$ of Pancreatic ribonuclease $\mathrm{A} / \mathrm{ml}$ (Worthington Biochemical), $80 \mu \mathrm{g}$ of ribonuclease $T_{1} / \mathrm{ml}$ (Calbiochem, $5000 \mathrm{U} / \mathrm{mg}$ ) and $1 \mathrm{mg}$ bovine serum albumin/ml in $0.01 \mathrm{M}$ Tris $-\mathrm{C} 1, \mathrm{pH} 7.6$, and $0.01 \mathrm{M} \mathrm{NaCl}$. The RNAase was added together with the other reaction constituents. Acid precipitable radioactivity was determined as described before (16).

\section{RESULTS AND DISCUSSION}

\section{A) Purity of mRNA}

Calf lens 145 MRNA used in these experiments was purified by zonal centrifugation and oligo(dT)-cellulose chromatography. Identification of the translational products suggest that the $14 S$ mRNA preparation contained onty a minor contamination of other lens mRNAs (Fig. 1). 

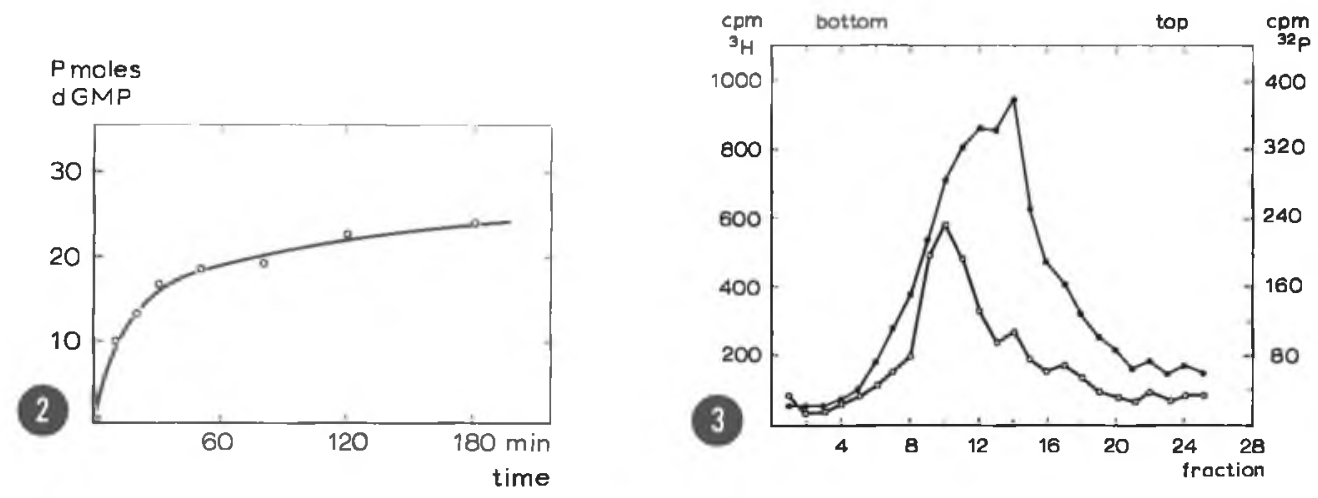

Figure 2. Kinetics of DNA synthesis using calf lens $14 S$ mRNA as a template. The reaction mixture described in the Method section was used, except that 2000 pmoles of RNA were added per $200 \mu 1$ reaction mixture. Aliquots of $20 \mu 1$ were withdrawn and the reaction was stopped by addition of $2 \%$ sarkosyl.

Figure 3. Alkaline sucrose gradient analysis of the DNA product.

The complete reaction mixture contained in $0.4 \mathrm{~m} 7$ was used, except 8000 pmoles of RNA was added along with $3 \mathrm{H} \mathrm{dCTP}$ (28 Ci/mmole). Marker globin DNA was prepared as described before (1). The DNA was purified by G-50 gel filtration as described before (20). 5 to $20 \%$ alkaline sucrose gradients containing $0.7 \mathrm{M} \mathrm{NaCl}, 1.0 \mathrm{mM}$ EDTA and $0.3 \mathrm{M} \mathrm{NaOH}(\mathrm{pH} 12.4)$ were freshly prepared. Centrifugation was performed in a SW 56 rotor of the Beckman ultracentrifuge at $56,000 \mathrm{rpm}$ for 14 hours at $2^{\circ} \mathrm{C}$. The gradients were fractionated into 25 to 30 fractions and radioactivity counted after the addition of $5 \mathrm{ml}$ of Instagel (Packard).

$\because-\longrightarrow 3 \mathrm{H}$ lens DNA

$\rightarrow 0-0-0-0$ 32P 8 S globin DNA

\section{B) Kinetics of transcription}

When the I4S MRNA was used as a template in the standard reaction mixture, extensive polymerization of deoxyribonucleoside triphosphates was observed in the presence of oligo(dT) primer. The requirements of the reaction are summarized in Table 1. In the presence of Actinomycin D incorporation was inhibited by about $40 \%$. Actinomycin D prevents the synthesis of double stranded DNA $(1,17)$. A11 4 deoxyribonucleoside triphosphates are required for the synthesis of complementary DNA. Ribonuclease almost completely inhibits incorporation of deoxyribonucleoside triphosphates. Although oligo(dT) is the most efficient primer it can be replaced by an oligo(dG) primer. This has also been observed in the synthesis of DNA complementary to globin mRNA $(1,18)$. The extent of DNA synthesis varied from one experiment to another even when the same RNA preparation was used.

If the four deoxyribonucleoside monophosphates are present in approximately equimolar amounts in the DNA transcript then the amount of dGMP incorporation multiplied by four will give the extent of transcription. In most experiments the transcription amounted to $20-60 \%$ of the input RNA. Fig. 2 shows the kinetics of 
synthesis of complementary DNA. The maximal synthesis was achieved between 120 to 180 min. of incubation. The amount of incorporation was proportional to the amount of RNA added. However at elevated RNA concentrations the incorporation is no longer linear (above 15,000 pmoles of nucleotide/ml).

C) Size of the complementary DNA

Figure 3 depicts the sedimentation pattern of the DNA on an alkaline sucrose gradient. The complementary 85 rabbit globin DNA was included as marker. The DNA complementary to the 14S lens mRNA appears slightly smaller and more heterogenous than globin DNA. Since the 145 mRNA appears larger than the 10S globin mRNA (a1though it directs the synthesis of a polypeptide with a molecular weight of only $20,000)$ this indicates that the mRNA is only partially transcribed or has been transcribed in several pieces.

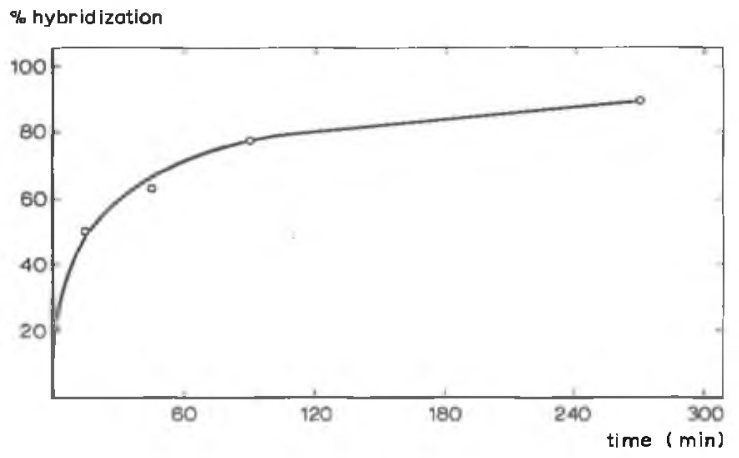

Figure 4. Hybridization of the DNA product with the 14S MRNA.

High specific activity labeled DNA transcript (2400 $\mathrm{cpm}$ of $3 \mathrm{H} \mathrm{dGMP} / \mathrm{pmole}$ ) was made using the complete reaction mixture described in the Method section. The DNA was purified as described before (20). DNA-RNA hybridization was performed in $10 \mu 1$ capilliary tubes in a medium containing $0.2 \mathrm{M}$ phosphate buffer, $\mathrm{pH} 7.0$ and $0.5 \%$ SDS. After heating the mixture for $5 \mathrm{~min}$. at $95^{\circ} \mathrm{C}$ the capilliary tubes were transferred immediately to a $65^{\circ} \mathrm{C}$ waterbath. After hybridization the capilliary tubes were cooled in ice, broken and the solution expelled into $1.0 \mathrm{ml}$ of digestion buffer $(1 \mathrm{mM} \mathrm{ZnSO}, 0.1 \mathrm{M}$ sodium acetate, $\mathrm{pH} 4.5$ and $10 \mu \mathrm{g} / \mathrm{ml}$ calf thymus DNA). $6 \mu 1$ of Aspergillus single strand nuclease was added and the solution was incubated at $45^{\circ} \mathrm{C}$ for $30 \mathrm{~min}$. Acid-precipitable radioactivity was determined. The hybridization mixture in each capilliary contained 1 pmole of complementary DNA and 100 pmol 14S mRNA.

The same situation has been encountered with the transcription of the AMV RNA where oniy DNA pieces of 5 to 7 were synthesized (17). It is possible that the secondary structure of the $14 S$ crystallin mRNA and the AMV-RNA prevent their complete transcription.

(D) Nature of the product

To determine if a faithful transcript of DNA complementary to the 145 mRNA was synthesized we studied the ability of the DNA to hybridize with the RNA 
template. The kinetics of hybridization are shown in Figure 4 . About $90 \%$ of the DNA annealed to the RNA, indicating that the DNA product is a faithful transcript of the lens mRNA. Some self annealing could be detected in the absence of RNA suggesting that either the synthesis of double stranded DNA is not completely inhibited by actinomycin D or the single stranded DNA formed "hairpins". The extent of self annealing was substracted from the RNA-DNA annealing values. When the DNA was hybridized to tRNA or 10S globin mRNA it remained completely sensitive to single strand specific nuclease.

\section{CONCLUSION}

The $14 \mathrm{~S}$ calf lens mRNA can be transcribed into complementary DNA using purified DNA polymerase from AMV. The product though smaller in size than the template is a faithful transcript of the template. Attempts are being made to determine if there are any homologies in the base sequences of various fractions of calf lens mRNAs using the labeled complementary DNA as a probe. We are also trying to transcribe the complementary DNA into RNA by E. coli RNA polymerase in an attempt to synthesize labeled RNA for nucleotide sequences analysis. The availability of labeled complementary DNA will also enable us to determine the number of gene copies of $\alpha$-crystal1 in 145 mRNA in the calf lens.

\section{ACKNOWLEDGEMENT}

The present investigations have partly been carried out under the auspices of the Netherlands Foundation for Chemical Research (SON) with financial aid of the Netherlands Organization for the Advancement of Pure Research (ZWO) and a contract to D. BaItimore from the Special Virus Cancer Program of the National Cancer Institute. Stephen J. Kaufman and Inder M. Verma were fellows of the Jane Coffin Child Memorial Fund for Medical Research.

We are thankful to Drs. A. Rich and D. Baltimore in whose Taboratories this work was performed.

\section{REFERENCES}

1. Verma, I.M., Temple, G.F., Fan, H. and Baltimore, D. (1972). Nature New Biology 235, 163-167.

2. Kacian, D.L., Spiegelman, S:, Bank, A., Terada, M., Metafora, S., Dow, L. and Marks, P.A. (1972). Nature New Biology 235, 167-169.

3. Ross, J., Aviv, H., Scolnick, E. and Leder, P. (1972). Proc. Nat1. Acad. Sci. U.S.A. $69,264-268$.

4. Zassenhous, P. and Kates, J. (1972). Nature New Biology 238, 139-141.

5. Verma, I.M. and Baltimore, D. (1973). Methods in Enzymology, in press.

6. Verma, I.M. and Firtel, R.A., manuscript in preparation.

7. Slater, D.W., Slater, I. and Gillespie, D. (1972). Nature, 240, 333-337.

8. Piperno, G., Bertazzoni, U., Berns, A. and Bloemendal, H., manuscript in preparation.

9. Berns, A.J.M., Strous, G.J.A.M. and Bloemendal, H. (1972). Nature New Biology 236, 7-9. 
10. Mathews, M.B., Osborn, M., Berns, A.J.M. and Bloemenda 1, H. (1972). Nature New Biology $236,5-7$.

11. Berns, A.J.M., van Kraaikamp, M., Bloemendal, H. and Lane, C.D. (1972). Proc.Nat7. Acad.Sci. U.S.A. 69, 1606-1609.

12. Berns, A.J.M., Schreurs, V.V.A.M., van Kraaikamp, M. and Bloemendal, H. (1973). Eur. J. Biochem. 33, 551-557.

13. Bloemenda1, H., Schoenmakers, J.G.G., Zweers, A., Matze, R. and Benedetti, E.L. (1966). Biochim.Biophys. Acta 123, 217-220.

14. Perry, R.P., La Torre, J., Kelley, D.E. and Greenberg; J.R.(1972). Biochim. Biophys. Acta, 262, 220-226.

15. Aviv, H. and Leder, P. (1972). Proc.Nat1.Acad.Sci. U.S.A., 69, 1408-1412.

16. Baltimore, D., Huang, A.S. and Stampfer, M. (1970). Proc.Natl.Acad.Sci. U.S.A. $66,572-576$.

17. Temin, H. and Ba7timore, D. (1972). Advances in Virus Research 17, 129, Academic Press, Inc., New York and London.

18. Verma, I.M., Temple, G.F., Fan, H. and Baltimore, D. (1973). "Symposium on Control of Transcription" held at Calcutta, India Feb. 12-15, to be published.

19. Laemm1 i, U.K. (1970). Nature 227, 680-685.

20. Verma, I.M., Meuth, N.L., Bromfield, E., Manly, K.F. and Baltimore, D. (1971). Nature New Biology 233, 131-134. 
